\title{
Genetic Variability Studies of Turmeric (Curcuma longa L.) Genotypes of North Eastern Region of India
}

\author{
Solei Luiram ${ }^{1,4}$, P.C. Barua ${ }^{1}$, L. Saikia ${ }^{1}$, M.C. Talukdar ${ }^{1}$, S. Luikham², \\ H. Verma ${ }^{3}$ and P. Sarmah ${ }^{3}$ \\ ${ }^{1}$ Department of Horticulture, ${ }^{2}$ Department of Plant Pathology, ${ }^{3}$ Department of Plant \\ Breeding and Genetics, Assam Agricultural University, Jorhat- 785013, Assam, India \\ ${ }^{4}$ KVK, Ukhrul, ICAR Research Complex for NEH Region, Manipur-795142
}

*Corresponding author

\section{A B S T R A C T}

\begin{tabular}{|c|}
\hline Keywords \\
\hline $\begin{array}{l}\text { PCV, GCV, } \\
\text { Heritability, } \\
\text { Genetic advance }\end{array}$ \\
\hline Article Info \\
\hline $\begin{array}{l}\text { Accepted: } \\
\text { 26 June } 2018 \\
\text { Available Online: } \\
\text { 10 July } 2018\end{array}$ \\
\hline
\end{tabular}

Thirty two (32) genotypes of turmeric from all the north eastern state of India along with Duggirala Red as check variety were evaluated to study the genetic parameters in respect of yield and yield attributing characters. Fifty three (53) traits were analyzed for phenotypic coefficient of variation (PCV), genotypic coefficient of variation (GCV), heritability $\left(\mathrm{h}^{2}\right)$ and expected genetic advance at 5 per cent selection intensity. The study revealed the presence of significant genetic variability, moderate to high heritability along with good genetic advance as percent of mean. The genotypes giving higher values of these characters indicated that the individual plant selection based on these characters may be given more emphasis and hence better selection process for further crop improvement programme. Thus, the result of the present study demonstrated that there exists variability among different turmeric genotypes of north eastern region of India indicating high potential for effective crop improvement and/or for further manipulation of the genetic resources through breeding as the genotypes in this region are good sources of genes for many desirable traits.

\section{Introduction}

Creation of genetic variability, heritable variation and the expected genetic gain forms the basis for plant breeding. The availability of genetic variability among population is most important for judicious selection and breeding to desired plant genotypes in any future crop improvement programme. In order to conserve the genetic resources and get consistent variability, genetic studies of morphological characterization among turmeric genotypes are essential. The objective of the present study was to determine the patterns of distribution of morphological variations and genetic parameters for rhizome yield and yield determining characters in thirty two (32) turmeric genotypes collected from wide geographical range of north eastern region of India. 


\section{Materials and Methods}

The experiment was conducted at Horticulture Experimental Farm, AAU, Jorhat, Assam during 2016. The experimental materials were collected from the farmer's field from all the eight (8) north eastern state of India. The treatments comprises of 33 genotypes which were replicated thrice under Randomized Block Design (RBD). Plot size of $1.5 \mathrm{~m} \times 1.5$ $\mathrm{m}$ (2.25 sq. $\mathrm{m})$ was laid out with plant to plant spacing of $30 \mathrm{~cm} \times 30 \mathrm{~cm}$ accommodating 25 plants per plot. The analysis of variance was worked out according to the method suggested by Panse and Sukhatme (1989). The GCV and PCV were worked out according to Burton and Devane (1953). Subsequently, the heritability in broad sense and genetic advance as per cent of mean at $5 \%$ selection intensity were worked out respectively.

\section{Results and Discussion}

The nature and magnitude of genetic variations were studied for fifty three (53) traits of turmeric genotypes using genetical parameters like genotypic coefficient of variation $(\mathrm{GCV})$, phenotypic coefficient of variation (PCV), heritability in broad sense $\left(\mathrm{h}^{2}\right)$ and genetic advance (GA) as per cent of mean. The study revealed that the GCV varied from $4.73 \%$ for numbers of leaves per main shoot at 165 DAP to $55.98 \%$ for numbers of leaves per tiller at $105 \mathrm{DAP}$. Among the 53 traits of turmeric genotypes evaluated, twenty five (25) traits exhibited relatively high GCV, twenty one (21) characters are medium and the rest seven (7) characters have low genetic coefficient of variation (GCV). The high GCV exhibited were also reflected in a wide range of their mean values. In general, the GCV estimates is lower than the PCV estimates which was also found in the present study indicating the influence of environment.

Genetic variability parameters studied for 53 traits of phenotypic coefficient of variation
(PCV), genotypic coefficient of variation $(\mathrm{GCV})$, heritability $\left(\mathrm{h}_{\mathrm{bs}}{ }^{2}\right)$ and genetic advance as per cent of mean showed high GCV and PCV for weight of mother, primary and secondary rhizome per plant, fresh rhizome yield per plant, number of leaves per hill, number of tillers per hill, number of primary rhizome and curcumin contents indicating presence of variability in these traits. Whereas plant height, leaf length and width, number of leaves per main shoot, number of days to maturity, length and girth of mother, primary and secondary rhizome, harvest index, dry recovery, oleoresin content and dry rhizome yield per plant showed low GCV and PCV indicating presence of low genetic variability for these parameters. Similar results have also been reported by Prajapati et al., (2014), Jalata et al., (2011), Yudhvir et al., (2003) and Jalgaonkar et al., (1990). Generally, the differences between phenotypic and genotypic coefficient of variability for all the corresponding characters was small indicating that these characters were less influenced by the environment. Several workers indicated that genetic variability of important agronomic traits is predominantly additive genetic variance, while the non-additive genetic variance is generally smaller than the additive genetic variance (Moll and Stuber, 1974). Genotypic coefficient of variability estimate gives good implication for genetic potential in crop improvement through selection (Johnson et al., 1955). High values of GCV suggest better scope of improvement for these traits by selection. Burton (1952) suggested that the genetic coefficient of variation together with heritability estimates gave the better picture of heritable variations.

The broad sense heritability estimates of the character provide a measure of the effectiveness of selection on phenotypic basis for that particular character. In the present study most of the characters showed high heritability (> $80 \%$ ) for 39 characters, medium $(60-80 \%)$ for 9 characters and low 
heritability $(<60 \%)$ for the rest five (5) characters respectively. This showed that genetic determination for most characters were high with less environmental influence on the expression of characters. Panse (1957) reported that the genetic variations, heritability and genetic advance were high in the weight and number of finger rhizome per clump, tillers number per clump which indicated the effect of additive genes. Lynrah et al., (1998) reported tillers/clump and mother rhizome and finger rhizome yield components showed high genetic variation and high broad-sense heritability.

Table.1 Genetic variability estimation of different turmeric genotypes

\begin{tabular}{|c|c|c|c|c|c|c|c|}
\hline $\begin{array}{l}\text { Sl. } \\
\text { No. }\end{array}$ & Characters & Mean & Range & $\begin{array}{l}\text { PCV } \\
(\%)\end{array}$ & $\begin{array}{c}\text { GCV } \\
(\%)\end{array}$ & $\begin{array}{l}\text { Heritabi } \\
\text { lity (\%) }\end{array}$ & $\begin{array}{l}\text { GA\% } \\
\text { Mean }\end{array}$ \\
\hline 1 & Plant height $(\mathrm{cm}) 75$ DAP & 89.14 & $43.62-114.58$ & 16.94 & 16.22 & 0.95 & 44.00 \\
\hline 2 & Plant height $(\mathrm{cm}) 105$ DAP & 105.77 & $71.48-132.61$ & 14.06 & 13.50 & 0.95 & 36.87 \\
\hline 3 & Plant height $(\mathrm{cm}) 135$ DAP & 112.64 & $82.42-144.02$ & 13.74 & 13.30 & 0.96 & 38.25 \\
\hline 4 & Plant height $(\mathrm{cm}) 165$ DAP & 116.24 & $89.73-158.85$ & 14.21 & 13.88 & 0.98 & 40.41 \\
\hline 5 & Leaf length $(\mathrm{cm}) 75$ DAP & 45.06 & $26.59-56.96$ & 16.11 & 13.01 & 0.84 & 39.14 \\
\hline 6 & Leaf length $(\mathrm{cm}) 105$ DAP & 51.20 & $35.91-64.90$ & 14.90 & 13.53 & 0.83 & 35.21 \\
\hline 7 & gth $(\mathrm{cm}) 135$ DAP & 53.49 & $41.44-68.68$ & 15.86 & 14.45 & 0 . & 31.51 \\
\hline 8 & Leaf length $(\mathrm{cm}) 165$ DAP & 56.34 & $41.69-8$ & 15.86 & 14.45 & 0 . & 31.93 \\
\hline 9 & Leaf width (c & 13 & 9.0 & 14.55 & 9.30 & 0 . & 49.10 \\
\hline 10 & Leaf width (c & 14.72 & 11.0 & 18.41 & 15.23 & 0. & 26.22 \\
\hline 11 & Leaf width $(\mathrm{cm}) 135$ DAP & 15.21 & 11. & 14.60 & 10.09 & 0 . & 28.66 \\
\hline 12 & Leaf width ( & 15.90 & 8.56 & 13.66 & 9.79 & 0 . & 26.54 \\
\hline 13 & $n$ shoot 75 DAP & 6. & 39 & 18.04 & 7.46 & 0. & 31.29 \\
\hline 14 & Leaves/main shoot 105 DAP & 7.77 & $5.46-$ & 21.10 & 7.82 & 0.4 & 25.48 \\
\hline 15 & Leaves/main shoot 135 DAP & 8.54 & $6.48-10.38$ & 16.43 & 8.24 & 0.5 & 22.13 \\
\hline 16 & Leaves/main shoot $165 \mathrm{I}$ & 9.13 & $7.46-11.09$ & 17.25 & 4.73 & 0.2 & 9.20 \\
\hline 17 & Leaves/tiller 1 & 6.2 & 0.60 & 59.17 & 55.98 & 0. & 96.45 \\
\hline 18 & Leaves/tiller 135 DAP & 8.83 & $0.76-13.76$ & 49.40 & 46.48 & 0.9 & 94.00 \\
\hline 19 & Leaves/tiller 165 DAP & 10.17 & $3.36-18.88$ & 47.10 & 45.03 & 0.9 & 98.23 \\
\hline 20 & Leaves/hill 75 DAP & 7.65 & $5.05-16.33$ & 30.13 & 25.05 & 0.8 & 76.20 \\
\hline 21 & Leaves/hill 105 DAP & 12.38 & $7.51-17.34$ & 24.78 & 20.25 & 0.79 & 50.32 \\
\hline 22 & Leaves/hill 135 DAP & 14.81 & $8.55-23.48$ & 25.21 & 21.90 & 0.87 & 60.76 \\
\hline 23 & Leaves/hill 165 DAP & 17.19 & $11.82-28.34$ & 26.65 & 24.71 & 0.9 & 67.07 \\
\hline 24 & Tillers/hill 105 DAP & 1.7 & $0.54-2.79$ & 50.73 & 50.08 & 0.9 & 87.00 \\
\hline 25 & Tillers/hill 135 DAP & 2 & $0.77-3.44$ & 46.79 & 45.98 & 0.9 & 86.00 \\
\hline 26 & Tillers/hill 165 DAP & 2.1 & $1.12-3.48$ & 38.85 & 38.51 & 0.9 & 90.32 \\
\hline 27 & Days to maturity & 24 & $218.66-265.33$ & 5.33 & 4.93 & 0.8 & 9.49 \\
\hline 28 & Leaf area index at 1 & 24 & $1.17-4.94$ & 36.29 & 34.51 & 0. & 67.46 \\
\hline 29 & Leaf area index at165 DAP & 26 & $1.52-4.34$ & 28.93 & 26.80 & 0.8 & 51.75 \\
\hline 30 & Leaf area duration at165 DAP & 79.95 & $52.70-135.16$ & 27.75 & 26.72 & 0.92 & 50.13 \\
\hline 31 & Chlorophyll content $(\mathrm{mg} / \mathrm{g})$ & 0.07 & $0.046-0.123$ & 30.16 & 29.74 & 0.97 & 65.71 \\
\hline 32 & Photosynthesis $\left(\mu\right.$ mole $\left.\left(\mathrm{CO}_{2}\right) \mathrm{m}^{-2} \mathrm{~s}^{-1}\right)$ & 10.54 & $6.28-15.39$ & 24.62 & 23.43 & 0.90 & 45.35 \\
\hline
\end{tabular}




\section{Contd:}

\begin{tabular}{|c|c|c|c|c|c|c|c|}
\hline $\begin{array}{l}\text { Sl. } \\
\text { No. }\end{array}$ & Characters & Mean & Range & $\begin{array}{l}\text { PCV } \\
(\%)\end{array}$ & $\begin{array}{l}\text { GCV } \\
(\%)\end{array}$ & $\begin{array}{l}\text { Heritabi } \\
\text { lity }(\%)\end{array}$ & $\begin{array}{l}\text { GA \% } \\
\text { Mean }\end{array}$ \\
\hline 33 & Transpiration $\left(\mathrm{mmol}\left(\mathrm{H}_{2} \mathrm{O}\right) \mathrm{m}^{-2} \mathrm{~s}^{-1}\right)$ & 4.48 & $1.26-9.70$ & 52.90 & 51.44 & 0.93 & 89.00 \\
\hline 34 & $\begin{array}{l}\text { Stomatal conductance } \\
\left(\text { mole }\left(\mathrm{H}_{2} \mathrm{O}\right) \mathrm{m}^{-2} \mathrm{~s}^{-1)}\right.\end{array}$ & 0.179 & $0.09-0.33$ & 52.77 & 52.42 & 0.17 & 2.23 \\
\hline 35 & Internal $\mathrm{CO}^{2}\left(\mu \mathrm{mol} \mathrm{\textrm {mol } ^ { - 1 } )}\right.$ & 240.78 & $85.81-322.26$ & 23.77 & 23.41 & 0.97 & 47.00 \\
\hline 36 & Harvest index & 49.50 & $51.33-83.67$ & 17.25 & 11.78 & 0.21 & 7.23 \\
\hline 37 & Length of mother rhizome $(\mathrm{cm})$ & 6.32 & $4.52-8.48$ & 17.03 & 14.42 & 0.85 & 39.87 \\
\hline 38 & Length of primary rhizome $(\mathrm{cm})$ & 7.50 & $5.56-9.78$ & 17.89 & 15.16 & 0.86 & 41.86 \\
\hline 39 & Length of secondary rhizome $(\mathrm{g})$ & 7.50 & $5.7-9.78$ & 27.64 & 19.71 & 0.79 & 26.00 \\
\hline 40 & Girth of mother rhizome $(\mathrm{cm})$ & 3.26 & $2.56-4.91$ & 17.09 & 10.69 & 0.65 & 27.60 \\
\hline 41 & Girth of primary rhizome $(\mathrm{cm})$ & 1.51 & $1.22-2.52$ & 22.13 & 13.29 & 0.71 & 35.76 \\
\hline 42 & Girth of secondary rhizome $(\mathrm{cm})$ & 1.10 & $0.84-1.48$ & 17.38 & 12.69 & 0.80 & 32.72 \\
\hline 43 & Primary rhizome/ plant & 7.99 & $4.73-14.93$ & 30.51 & 28.84 & 0.94 & 78.09 \\
\hline 44 & Wt. of mother rhizome/plant (g) & 68.39 & $35.42-109.29$ & 27.84 & 26.08 & 0.92 & 56.66 \\
\hline 45 & Wt. of primary rhizome/plant (g) & 128.89 & 75.74-202.53 & 27.70 & 27.10 & 0.97 & 83.77 \\
\hline 46 & Wt. of secondary rhizome/pl. (g) & 68.33 & $35.07-97.25$ & 30.20 & 28.16 & 0.92 & 73.39 \\
\hline 47 & Fresh rhizome yield / plant (g) & 251.93 & $150.7-374.47$ & 25.52 & 24.77 & 0.97 & 70.96 \\
\hline 48 & Fresh rhizome yield / ha (qtls) & 279.92 & $166.67-413.89$ & 24.77 & 24.56 & 0.96 & 71.24 \\
\hline 49 & Dry rhizome yield / plant (g) & 49.30 & $30.02-68.38$ & 22.75 & 19.89 & 0.91 & 59.49 \\
\hline 50 & Dry rhizome yield / ha (qtls) & 39.77 & $24.02-55.35$ & 24.08 & 19.71 & 0.90 & 60.29 \\
\hline 51 & Dry recovery (\%) & 19.76 & $14.16-24.50$ & 14.96 & 12.54 & 0.69 & 21.25 \\
\hline 52 & Curcumin content (\%) & 4.36 & $1.72-6.51$ & 34.60 & 34.21 & 0.97 & 69.03 \\
\hline 53 & Oleoresin content (\%) & 12.63 & $7.63-17.52$ & 20.53 & 19.69 & 0.92 & 38.87 \\
\hline
\end{tabular}

Pathania et al., (1988) reported that curcumin content exhibited wide range, maximum genotypic coefficient of variation, heritability and genetic advance. Reddy and Rao (1988) observe high GCV, heritability and genetic advance for rhizome yield and number of primary fingers indicating high degree of genetic variability for these characters. Sasikumar and Sardana (1989) also observe maximum genetic advance for weight of fingers. Ramanujam and Thirumalachar (1967) indicated the limitations of estimating heritability in narrow sense as it includes both additive and epistatic gene effects and suggested that heritability estimates in broad sense will be reliable if accompanied by a high genetic advance. In the present study, the genetic advance as percent of mean at $5 \%$ selection intensity varied from $2.23 \%$ for stomatal conductance to 98.23 for number of leaves per tiller at 165 DAP. Subsequently, twenty four (24) traits have high genetic advance as per cent of mean, seventeen (17) traits have medium genetic advance as per cent of mean while the remaining twelve (12) traits showed low genetic advance as per cent of mean (Table 1).

High heritability along with high genetic advance as per cent of mean found in this study suggested the role of additive genes in the expression of the character which would effectively be improved upon selection. Thus, there is ample scope for improving these characters based on direct selection. These results are in agreement with the earlier 
findings of Rajalakhsmi et al., (2013), Hikmat et al., (2012), Jalata et al., (2011), Lynrah et al., (1998), Pathania et al., (1988) and Philips and Nair (1986). High heritability with appreciable genetic advance was reported for turmeric rhizome yield, crop duration, number of leaves, number of primary fingers, yield of secondary fingers and plant height (Yadav and Singh, 1996). Therefore selection for the above characters are expected to be effective for crop improvement programme.

In conclusion, the result of the present study demonstrated that there exists wide variability among different turmeric genotypes of north eastern region of India indicating high potential for effective crop improvement and/or for further manipulation of the genetic resources through breeding as the genotypes in this region are good sources of genes for many desirable traits. Summarizing the PCV, GCV, Heritability and Genetic advance characters, it can be concluded that the genotypes giving higher values of these characters may be given more emphasis and hence better selection process for further crop improvement programme.

\section{Acknowledgement}

The author expresses his thankful gratitude to Dr. Madhumita C. Talukdar, Professor \& Head, Department of Horticulture, AAU, Jorhat for providing necessary facilities to carry out the research work successfully.

\section{References}

Burton, G.W. 1952. Quantitative inheritance in grasses. Proc. Int. Grassland Congr., 1: 277-283.

Burton, G.W. and Devane, E.H. 1953. Estimating heritability in tall fescue (Festuca arundinacea) from replicated clonal material. Agronomy Journal, 45
(10): $478-481$.

Jalata, Z., Ayana, A. And Zeleke, H. 2011. Variability, Heritability and Genetic Advance for Some Yield and Yield Related Traits in Ethiopian Barley (Hordeum vulgare L.) Landraces and Crosses. International Journal of Plant Breeding and Genetics, 5: 4452.

Jalgaonkar, R., Jamadagni, B.M. and Selvi, M.J. 1990. Genetic variability and correlation studies in turmeric. Indian Cocoa, Arecanut and Spices Journal, 14: 20-22.

Johnson, H.W., Robinson, H.F. and Comstock, R. E. 1955. Genetic and environmental variability in soybean. Agron J. 47: 314-318.

Lynrah, P.G., Barua, P.K. and Chakrabarty, B.K. 1998. Pattern of genetic variability in a collection of turmeric (Curcuma spp) genotypes. Indian Journal of Genetics and Plant Breeding, 58(2): 201-207.

Moll, R.H. and Stuber, C.W. 1974. Quantitative genetics-empirical results relevant to plant breeding. $A d v$. Agron., 26: 277-313.

Panse, V.G. 1957. Genetics of quantitative characters in relation to Plant Breeding. Indian J. Genet., 17: 315 328.

Panse, V.G. and Sukhatme, P.V. 1989. Statistical Methaods for Agricultural Workers. IV ${ }^{\text {th }}$ Revised Edition, 1989, ICAR, New Delhi.

Pathania, N.K., Singh, P. and Singh, M. 1988. Variability studies in turmeric (Curcuma longa L.). Ind. J. Agril. Res., 22: 176 -178.

Philip, J. and Nair, P.C.S. (1986). Studies on variability, heritability, and genetic advance in turmeric. Ind. Cocoa Arec. Spices J., 10: 29-30.

Prajapati, K.N., Patel, M.A., Patel, J.R., Joshi, N.R. and Patel, A.D. 2014. Genetic 
variability, character association and path coefficient analysis in turmeric (Curcuma longa L.). Electronic Journal of Plant Breeding, 5 (1):131137.

Rajalakshmi, R., Naidu, L.N., Rajasekhar, M. and Sudhavani, V. (2013). Genetic variability, correlation and path coefficient analysis in turmeric (Cucurma longa L.). J. Spice and Aromatic Crops, 22: 104-107.

Ramanujam, S. and Thirumalachar, D.K. 1967. Genetic variability of certain characters in red pepper (Capsicum аппиит). Mysore J. Agric. Sci., 1: 30 -36 .

Reddy, M.L.N. and Rao, D.V.R. 1988. Genetic variability and association in turmeric (Curcuma longa L.). Proceedings of the National Seminar on Chillies, Ginger and Turmeric, held at Hyderabad on January 11-12, 1988, pp. 97-99.

Sasikumar, B. and Sardana, S. 1989. Genetic variability in turmeric (Curcuma longa L.). Journal of Hill Research, 2 (2): 187-191.

Yadav, D.S. and Singh, R. 1996. Studies on genetic variability in turmeric (Curcuma longa L.). Journal of Hill Research, 9: 33-36.

Yudhvir, S., Pankaj, M. and Viveka, K. 2003. Genetic variability and heritability in turmeric (Curcuma longa L.). Himachal Journal of Agricultural Research, 29 (1\&2): 31-34.

\section{How to cite this article:}

Solei Luiram, P.C. Barua, L. Saikia, M.C. Talukdar, S. Luikham, H. Verma and Sarmah, P. 2018. Genetic Variability Studies of Turmeric (Curcuma longa L.) Genotypes of North Eastern Region of India. Int.J.Curr.Microbiol.App.Sci. 7(07): 3891-3896. doi: https://doi.org/10.20546/ijcmas.2018.707.453 